\title{
Artikel
}

\section{Het recht om vergeten te worden na overlijden}

\author{
Lucienne van der Geld*
}

\section{Inleiding}

Op 13 mei 2014 deed het Hof van Justitie van de Europese Unie (hierna: het Hof) een uitspraak waardoor Google verplicht is persoonlijke informatie van een Spaanse staatsburger te verwijderen uit de zoekresultaten. In een voorstelverordening is dit 'recht om vergeten te worden' opgenomen. ${ }^{1}$ In deze bijdrage doet de auteur een eerste verkenning naar de vraag of dit 'recht om vergeten te worden' als persoonlijkheidsrecht overgaat op de erfgenamen (doorwerkt na overlijden) en daarmee naar de vraag of de uitoefening van dit recht in een uiterste wilsbeschikking kan worden toegekend aan de executeur dan wel aan (bepaalde) erfgenamen.

\section{Het vergeetrecht}

De Europese Commissie heeft op 25 januari 2012 een voorstel voor een algemene verordening gegevensbescherming gepubliceerd. ${ }^{2}$ Onderdeel van deze verordening is het 'recht om vergeten te worden'. In artikel 17

Mr. L.A.G.M. van der Geld is juridisch directeur van Netwerk Notarissen, kandidaat-notaris en als docent verbonden aan het Centrum voor Notarieel Recht van de Radboud Universiteit Nijmegen.

1. In het Engels wordt het vergeetrecht 'the right to be forgotten' genoemd, in het Frans 'le droit l'oubli'.

2. Voorstel voor een Verordening van het Europees Parlement en de Raad betreffende de bescherming van natuurlijke personen in verband met de verwerking van persoonsgegevens en betreffende het vrije verkeer van die gegevens (algemene verordening gegevensbescherming) $\operatorname{COM}(2012) 11$. De verordening dient ter vervanging van de privacyrichtlijn (95/46/EG) en de Wbp. van deze verordening (voorstel) is het vergeetrecht vastgelegd; dit houdt het recht in om te verlangen dat persoonsgegevens worden verwijderd en dat verdere verspreiding achterwege blijft. Het vergeetrecht komt eenieder toe over wie persoonsgegevens worden verwerkt, ongeacht nationaliteit of woonplaats. De algemene verordening gegevensbescherming is nog niet vastgesteld, maar heeft na vaststelling rechtstreekse werking in nationale wetgeving.

Op 13 mei 2014 deed het Hof een uitspraak in een zaak die een Spaans staatsburger in eigen land had aangespannen tegen een Spaanse uitgever van een dagblad en Google om gegevens te verwijderen. ${ }^{3}$ Deze zaak is gebaseerd op de thans geldende privacyrichtlijn 95/46/EG, die te zijner tijd vervangen wordt door de algemene verordening gegevensbescherming. In de privacyrichtlijn is het verwijderrecht opgenomen, dat verder wordt uitgewerkt in het vergeetrecht van artikel 17 van de verordening. ${ }^{4}$ Het Hof oordeelde onder meer dat de zoekresultaten onder de privacywetgeving vallen en dat dit ook geldt als het gaat om een verwijzing naar elders gepubliceerde gegevens. Een exploitant van een zoekmachine is volgens het Hof 'onder bepaalde voorwaarden verplicht om van de resultatenlijst die na een zoekopdracht op de naam van een persoon wordt weergegeven, koppelingen

3. Het Spaanse agentschap voor de gegevensbescherming, AEPD (Agencia Española de Protección de Datos), heeft de tegen Google Spain en Google Inc ingediende klacht gegrond verklaard, waarop beide ondernemingen bij de Audiencia Nacional in Spanje tegen het besluit van de AEPD in beroep zijn gegaan. Vervolgens heeft de Audiencia Nacional een aantal prejudiciële vragen aan het Europese Hof voorgelegd. Dit leidde tot het arrest van het Europese Hof op 13 mei 2014, zaak C-131/112, ECLI:EU:C:2014:317.

4. Zie meer uitgebreid over de privacyrichtlijn, de verordening gegevensbescherming en het recht om vergeten te worden: G.J. Zwenne, Nog veel onzekerheden over het recht om te worden vergeten, Tijdschrift voor Internetrecht 2012, afl. 3, p. 68-76. 
te verwijderen naar door derden gepubliceerde webpagina's waarop informatie over deze persoon te vinden is' De exploitant van de zoekmachine kan daartoe ook verplicht zijn 'indien deze naam of deze informatie niet vooraf of gelijktijdig van deze webpagina's is gewist en, in voorkomend geval, zelfs wanneer de publicatie ervan op deze webpagina's op zich rechtmatig is'. In deze zaak betrof het de vermelding in een Spaans dagblad van de openbare verkoop in verband met beslaglegging op gebouwen in 1998 van de Spaanse man. Bij het 'googelen' van zijn eigen naam kwam de Spaanse man nog steeds de vermelding van 1998 in de zoekresultaten tegen. Het 'recht te worden vergeten' leidt er volgens het Hof toe dat de inmiddels niet meer relevante openbare verkoop uit het verleden moet worden vergeten, ook al heeft de Spaanse man geen directe schade. Het Hof maakte voor het oordeel een afweging tussen de privacy enerzijds en de informatievrijheid anderzijds. Resultaat van het arrest van het Hof is dat Google de links naar deze publicatie moet verwijderen. Inmiddels zouden verschillende verzoeken tot 'verwijdering' van andere burgers bij Google zijn binnengekomen. ${ }^{5}$

\section{Opvolging in persoonlijkheidsrechten}

Het vergeetrecht is een modaliteit van het grondrecht op privéleven dat beschermd wordt door artikel 8 van het Europees Verdrag tot bescherming van de rechten van de mens en de fundamentele vrijheden (EVRM). Het vergeetrecht is een zogenaamd 'persoonlijkheidsrecht' het is geen vermogensrecht in de zin van artikel 3:6 van het Burgerlijk Wetboek (BW). Tot de persoonlijkheidsrechten behoren onder meer grondrechten, zoals het recht op bescherming van de lichamelijke integriteit, de persoonlijke levenssfeer, eer en goede naam en bewegingsvrijheid, aldus Asser/Bartels \& Van Mierlo. ${ }^{6}$ Naast het persoonlijkheidsrecht voortvloeiende uit de grondrechten uit de Nederlandse Grondwet (Gw) en het EVRM kennen we ook het persoonlijkheidsrecht voortvloeiend uit de Auteurswet.

Kunnen erfgenamen namens de overledene het vergeetrecht van artikel 17 van de algemene verordening gegevensbescherming inroepen? In de verordening kan daar geen antwoord op worden gevonden. Geeft het Nederlandse erfrecht een antwoord op die vraag? Door de werking van artikel 4:182 BW gaan in ieder geval betrekkingen van vermogensrechtelijke aard van de erflater over op de erfgenamen. In lid 1 van dit artikel staat: 'met het overlijden van de erflater volgen zijn erfgenamen van rechtswege op in zijn voor overgang vatba-

5. Reuters.com: 'Google gets take-down requests after European court ruling: source', 14 mei 2014.

6. Asser/Bartels \& Van Mierlo 3-IV 2013/1. re rechten en in zijn bezit en houderschap' ${ }^{7}$ Met de woorden 'voor overgang vatbare rechten' wordt aangegeven dat ook niet-vermogensrechtelijke rechten kunnen overgaan. Als hiervan sprake is, wordt dit buiten het erfrecht geregeld. Voorbeeld hiervan zijn onder meer het recht de gerechtelijke vaststelling van het vaderschap te verzoeken als bedoeld in artikel 1:207 BW, de bevoegdheden voortvloeiend uit artikel 19 en 20 Auteurswet en de hoogstpersoonlijke bevoegdheden als bedoeld in artikel 25 Auteurswet. ${ }^{8}$ In de Grondwet staat niet een bepaling over de overgang van rechten na overlijden. ${ }^{9}$

Door de horizontale werking van de grondrechten spelen deze ook een rol in het privaatrecht. Een aantasting van de persoonlijkheidsrechten voortvloeiend uit de grondrechten kan als onrechtmatige daad worden beschouwd. Op grond van artikel 6:162 BW kan een vordering tot schadevergoeding worden ingesteld tegen de overtreder dan wel rectificatie worden geëist (art. 6:167 BW). Als aan alle vereisten van artikel 6:162 BW is voldaan, is er een vordering uit onrechtmatige daad. Deze vordering gaat over op de erfgenamen, met inachtneming van de verjaringstermijn. Schending van het vergeetrecht is, neem ik aan, eerst aanwezig als een persoon daar een beroep op heeft gedaan en de ander geen gehoor heeft gegeven de gevraagde gegevens te verwijderen. Als erflater tijdens leven een beroep heeft gedaan op het vergeetrecht en de 'wederpartij' heeft daar (nog) geen gehoor aan gegeven, ga ik er gezien het voorgaande van uit dat de vordering op grond van het vergeetrecht 'vererft' op de erfgenamen. Een vordering uit onrechtmatige daad kunnen de erfgenamen alleen instellen als zij kunnen antonen dat erflater (vermogensrechtelijke) schade heeft ondervonden van de nietverwijdering van de gegevens; erflater verzocht dan tijdens leven om verwijdering van de gegevens. Het recht van erflater op vergoeding van niet-vermogensrechtelijke (ideële) schade gaat niet over op de erfgenamen (art. 6:106 lid $2 \mathrm{BW}$ ). Dit is alleen anders als erflater tijdens leven aan de wederpartij heeft meegedeeld aanspraak te maken op de vergoeding. Op grond van artikel 6:106 lid 1 sub c BW is er een zelfstandig recht op ideële schadevergoeding bij aantasting van de nagedachtenis van een overledene, die is toegebracht aan de niet van tafel en bed gescheiden echtgenoot, de geregistreerde partner of een bloedverwant tot in de tweede graad van de overledene. Vereist is dat als erflater nog in leven zou zijn geweest de aantasting aan erflater recht zou hebben gegeven op schadevergoeding wegens het schaden van zijn eer of goede naam. ${ }^{10}$

7. Asser/Perrick 4 2013/437 en 438, Handboek Erfrecht (5de druk), Deventer: Kluwer 2011, XIII.2 en L.C.A. Verstappen, Rechtsopvolging onder algemene titel, Deventer/Amsterdam: Kluwer/Stichting tot bevordering der Notariële Wetenschap Amsterdam 1996, 4.1

8. Zie voor meer voorbeelden: Asser/Perrick 4 2013/438 en 439.

9. Een uitzondering vormt art. $24 \mathrm{Gw}$, waarin het erfelijk koningschap is geregeld.

10. Over de overgang van ideële schadevergoeding: Asser/Hartkamp \& Sieburgh 6-II 2013/147. 
Als erflater tijdens leven geen beroep heeft gedaan op het vergeetrecht, kunnen erfgenamen dan het vergeetrecht uitoefenen ten aanzien van gegevens van erflater? Gegevens van overleden personen vallen niet onder de definitie van artikel $1 \mathrm{sub}$ a van de Wet bescherming persoonsgegevens (Wbp). ${ }^{11}$ Een dergelijke toelichting is er niet op de definities opgenomen in artikel 4 van de algemene verordening gegevensbescherming; ${ }^{12}$ in het bijzonder zijn van belang de definities 'betrokkene' en 'persoonsgegevens'. Bij een beroep door de erfgenamen op het vergeetrecht, zo dit beroep mogelijk is, zal door de rechter moeten worden bezien wat eraan ten grondslag ligt. ${ }^{13}$ Handelen de erfgenamen namens erflater om die gegevens te laten verwijderen die erflater verwijderd zou willen hebben omdat ze niet meer relevant (verouderd) zijn, zoals in de hiervoor besproken zaak bij het Hof, of gaat het de erfgenamen erom die gegevens te verwijderen omdat die gegevens hen hinderen erflater te herinneren op de wijze zoals zij dat wensen? Als het gaat om gegevens die erflater zelf verwijderd zou willen hebben, dan lijkt mij een beroep op het vergeetrecht mogelijk. Er zijn andere persoonlijkheidsrechten waarop ook na overlijden nog een beroep namens een overleden persoon kan worden gedaan, bijvoorbeeld het recht op eerbied voor het lijk, het recht op bescherming van eer en goede naam, enzovoort. Het vergeetrecht past in deze rij, nu het verwantschap heeft met het recht op bescherming van eer en goede naam.

Een beroep op het recht een overledene op een eigen manier te herinneren kan naar mijn mening niet worden gebaseerd op het vergeetrecht en zal een andere rechtsgrond behoeven.

\section{Uiterste wil en uitoefening persoonlijkheidsrechten}

Op 2 mei 2014 deed de Rechtbank Overijssel een uitspraak over de vraag wie kon beslissen over door de zoon en echtgenoot van erflaatster gevorderde obductie op het lichaam van erflaatster. ${ }^{14}$ In haar testament had erflaatster haar echtgenoot (een echtscheidingsprocedure was aanhangig) en haar zoon uitgesloten als erfgenamen. Haar dochter benoemde zij tot executeur, waarbij zij in haar testament vermeldde: 'Indien en voor zover ik persoonlijkheidsrechten heb als bedoeld in artikel 25 lid 1 van de Auteurswet of andere soortgelijke aan mijn persoon gebonden rechten, wijs ik hierbij uitdrukkelijk de executeur aan als persoon die deze rechten kan uitoe-

11. Kamerstukken II 1997/98, 25892, 3, p. 47.

12. Zie noot 2 .

13. In het arrest Erven Ouwendijk, HR 8 januari 1981, NJ 1982/423, oordeelde de Hoge Raad in het kader van herroepen testamenten dat een zwaarwegend belang toekomt aan respectering van informatie over erflater: ' $(. .$.$) herroepen testamenten, die veelal de neerslag vormen van$ door de erflater blijkens de latere herroeping als achterhaald beschouwde met zijn toenmalige levenssituatie verband houdende beweegredenen (...).'

14. Rb. Overijssel 2 mei 2014, ECLI:NL:RBOVE:2014:2343 (kort geding). fenen.' Volgens de rechter vormt het recht op onaantastbaarheid van het menselijke lichaam (art. $11 \mathrm{Gw}$ ) een persoonlijkheidsrecht dat doorwerkt na overlijden. Als executeur aan wie de uitoefening van de 'aan mijn persoon gebonden rechten' zijn toegekend, kan de dochter volgens de rechter beslissen of de obductie al dan niet plaatsvindt.

Mede uit deze uitspraak blijkt van de mogelijkheid voor een testateur zijn persoonlijkheidsrechten toe te kennen aan één of meer erfgenamen dan wel een executeur. In de testamentenpraktijk is dit naar mijn waarneming geen regelmatig voorkomende uiterste wilsbeschikking. Als erflater niet bij uiterste wilsbeschikking over zijn persoonlijkheidsrechten beschikt, dan komen deze, zo deze doorwerken na overlijden, toe aan de erfgenamen. $\mathrm{Bij}$ het in een testament beschikken over de persoonlijkheidsrechten kan mijns inziens worden bepaald welke persoonlijkheidsrechten wel en welke niet namens erflater kunnen worden uitgeoefend. Omdat het uitoefenen van een persoonlijkheidsrecht zonder nadere opdracht niet tot de taken van de executeur zal behoren, is het nodig, als erflater wil dat de executeur deze rechten uitoefent, dit bij de executele te vermelden. Als dat niet is gebeurd, oefenen de erfgenamen (ondanks de in functie zijnde executeur) de persoonlijkheidsrechten van erflater uit. Het belang van het kunnen uitoefenen van de persoonlijkheidsrechten was in de zaak van de RechtÄbank Overijssel groot: de executeur gaf aan geen obductie te wensen op het lichaam van erflaatster. De echtgenoot van erflaatster wilde graag bevestigd zien of erflaatster al dan niet aan een ziekte leed, omdat het de wens van erflaatster en niet van hem was te scheiden. De zoon wilde met de obductie nadere inlichtingen verkrijgen over de gezondheidstoestand van zijn moeder en haar doodsoorzaak.

\section{Tot slot}

Het recht om vergeten te worden kan mogelijk als persoonlijkheidsrecht doorwerken na overlijden. De erfgenamen kunnen dit recht dan namens de erflater uitoefenen. Bij uiterste wilsbeschikking kan erflater de uitoefening van een persoonlijkheidsrecht aan één of meer erfgenamen en/of de executeur toekennen. De erflater en zijn erfgenamen kunnen een belang hebben bij het verwijderen van informatie op het internet over het verleden van erflater. De rechter makt bij het beroep op het recht om vergeten te worden een afweging tussen het recht op privacy enerzijds en de informatievrijheid anderzijds. Naast het recht om vergeten te worden zijn er andere persoonlijkheidsrechten. Deze eerste verkenning levert het inzicht op dat persoonlijkheidsrechten een onderwerp van gesprek kunnen zijn bij het bespreken van iemands testament. Daarbij kan dan aan de orde worden gesteld welke persoonlijkheidsrechten wel en niet kunnen worden uitgeoefend na overlijden en door welke personen (erfgenamen en/of executeur). 